\title{
Konsep Pendidikan Islam Dalam Membentuk Manusia Paripurna
}

\author{
MUSADDAD HARAHAP* \\ LINA MAYASARI SIREGAR** \\ Fakultas Agama Islam (FAI) Universitas Islam Riau (UIR) Pekanbaru \\ Jln. Kaharuddin Nasution, No. 113 Perhentian Marpoyan Pekanbaru 28284 \\ Email: musaddadharahap@fis.uir.ac.id \\ $* *$ \\ STAI Barumun Raya Sibuhuan \\ Jln. Ki Hajar Dewantara, No. 66 Kab. Padanglawas Kode Pos 22763 \\ Email: linamayasarisiregar21@gmail.com
}

\begin{abstract}
In theological level, Islam believes that something outside of Allah is called nature. The nature that shapes as being is the radiance of the essential being that never diminishes and increases. When the True Beings change and grow theoretically it must be said not God. That is why God is the Supreme Creator (Khaliq) that nothing is similar to Him. God who has the nature afal with His will creates creatures. This being in Islam is not qodim but baharu. Herein lies the basic difference between God as the creator and the nature that is new. With the nature of this natural baharunya inevitably must be positioned as a form that has the potential to change. The potential for humans and nature to change is also part of the Islamic Education discourse. Such topics become important because by understanding the concepts that educational efforts in transforming science and values will be more likely to succeed. But the change aspired by Islamic education should remain in its domain of avoiding friction that can cause mafsadat-manfsadat (damage) both to the human self itself and the environment on a small scale and wide.
\end{abstract}

\section{Keywords: Concept, Islamic Education, Insan kamil}

Abstrak: Dalam tataran teologis, Islam meyakini sesuatu yang berada di luar diri Allah SWT dinamakan alam. Alam yang membentuk sebagai wujud merupakan pancaran dari Wujud Hakiki yang tidak pernah berkurang dan bertambah. Bila Wujud Hakiki berubah dan bertambah secara teoritis pastilah dikatakan bukan Tuhan. Itulah sebabnya Tuhan merupakan sang pencipta Agung yang tidak ada sesuatupun yang serupa dengan-Nya. Tuhan yang memiliki sifat af'al dengan kehendakNya terciptalah makhluk. Makhluk ini dalam Islam sifatnya tidak qodim tapi baharu. Disinilah letak perbedaan dasar antara Tuhan sebagi pencipta dengan alam yang bersifat baharu. Dengan sifat baharunya alam ini pada akhirnya mau tidak mau haruslah diposisikan sebagai wujud yang berpotensi mengalami perubahan. Salah satu alam itu adalah manusia, karenanya manusia juga terbuka luas potensinya untuk berubah. Topik semacam ini menjadi penting karena dengan memahami konsep itulah usaha pendidikan dalam mentransformasi ilmu dan nilai akan lebih memungkinkan untuk berhasil.

Kata Kunci: Konsep, Pendidikan Islam, Manusia Paripurna 


\section{PENDAHULUAN}

Pendidikan adalah persoalan yang tidak pernah selesai. Siapapun dan apapun profesinya pasti berhak untuk berbicara tentang pendidikan karena memang pendidikan bahagian yang tidak terpisahkan dari kehidupan manusia. Kemungkinan lain setiap orang punya wewenang berbicara pendidikan karena dalam diri manusia ada semacam tabiat atau naluri untuk menjadi pendidik. Namun tidak semua pembicaraan tema pendidikan lantas dapat menjadi barometer untuk dijadikan regulasi normatif dalam menumbuhkan kembangkan manusia berskala kecil maupun besar. Memang manusia butuh bantuan dan bantuan itu merupakan pendidikan, tapi tidak setiap bantuan serta merta dapat dikatakan pendidikan. Seperti perilaku spontan membantu orang yang mengalami kecelakaan lalu lintas. Bila merujuk kepada makna esensi pendidikan tentulah dapat dikatakan bahwa hal itu bukanlah pendidikan. Pendidikan sesungguhnya haruslah didasari oleh kesadaran penuh mendalam dalam menempatkan posisi manusia sesuai dengan kodrat bawaannya, tanpa memaksakan kehendak yang tidak argumentatif.

Sepintas, merujuk ke zaman Yunani Kuno, pembicaraan pendidikan dikalangan para pemikir masa itu cukup intens dan sudah terorganisir sedemikian rupa. Bagi mereka pada masa itu pendidikan adalah usaha sadar untuk membantu manusia menjadi manusia. Seseorang dapat dikatakan manusia bila benar-benar telah memiliki nilai-nilai kemanusia secara utuh. Jika tidak, manusia telah gagal menjadi manusia dan manusia telah gagal menjadikan manusia untuk menjadi manusia. Sampai pada tahap ini dengan samar-samar terlihat bahwa sudah ada perumusan tujuan yang dapat diukur sehingga program dapat disusun yaitu melalui ciri-ciri manusia yang menjadi impian mereka pada zaman itu. (Tafsir, 2008: 33).
Jadi persoalan sekarang, seperti apa kriteria manusia yang menjadi tujuan pendidikan? tentu jawaban terhadap pertanyaan tersebut kembali kepada falsafat hidup masing-masing. Artinya cara pandang terhadap apa dan siapa manusia itu biasanya akan melahirkan perlakuan-perlakuan yang lama-kelamaan menjelma menjadi sebuah kebijakan (sistem) sebagai panduan operasionalisasi dalam mewujudkan cita-cita yang ada. Dari sinilah terbentuknya kerangka atau bentuk pendidikan antara bangsa, kelompok, agama dengan lainnya. Apalagi jika melihat kenyataan sekarang adanya koeksistensi antara bangsa dengan bangsa lain, antara kelompok dengan kelompok lain membuat perbedaan implementasi pendidikan semakin hari semakin tajam perbedaannya. Paradoks pun menjadi fenomena dalam kehidupan diruangruang publik karena tidak adanya keseragaman falsafah kehidupan yang juga akan mempengaruhi pelaksanaan pendidikan. Mau tidak mau hal itu harus dimaklumi sebagai bagian dari kemajemukan umat manusia.

Islam adalah salah satu yang memiliki cara pandang tentang manusia. Terhitung dari tahun $1438 \mathrm{M}$ yang silam, Islam sudah meletakkan konsep-konsep yang cukup argumentative tentang dasardasar pendidikan dalam mengembangkan dan menjaga kehidupan umat manusia dan alam sekitarnya. Peletakan dasardasar pendidikan dalam Islam bermula dari konfirmasi Allah SWT kepada Nabi Muhammad SAW yang di-tadwin oleh para sahabat Nabi dalam bentuk mushab atau kitab yaitu Alqur'an dan Sunnah. Kedua kitab ini menjadi sumber primer dalam setiap merumuskan gagasan dan pengambilan keputusan pendidikan Islam. Hal inilah yang dimaksudkan dalam sebuah hadits, yaitu:

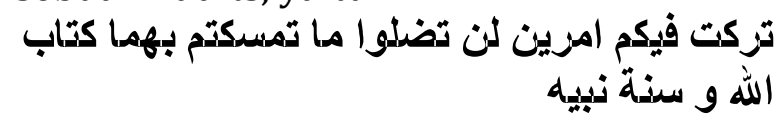


"Aku tinggalkan kepada kalian dua perkara yang kalian tidak akan tersesat selamanya selama berpegang teguh dengan keduanya, Kitabullah dan Sunnah"

Selain kitab Allah dan sunnah Nabi, untuk membantu pengembangan pendidikan Islam juga dijiwai oleh Ijma' dan Ijtihad yang merupakan hasil konsensus para sahabat dan ulama. Ijma' dan Ijtihad ini dalam konsep Islam ditempatkan sebagai sumber skunder. Ketentuan ini cukup beralasan seperti terlihat dalam Firman Allah SWT:

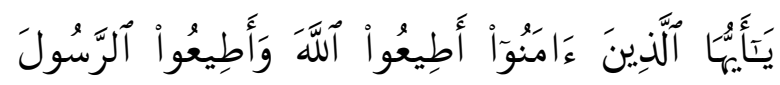

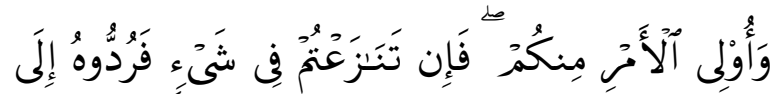
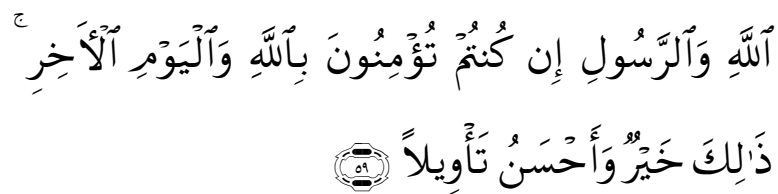

"Hai orang-orang yang beriman, taatilah Allah dan taatilah Rasul (Nya), dan ulil amri di antara kamu. kemudian jika kamu berlainan Pendapat tentang sesuatu, Maka kembalikanlah ia kepada Allah (Al Quran) dan Rasul (sunnahnya), jika kamu benarbenar beriman kepada Allah dan hari kemudian. yang demikian itu lebih utama (bagimu) dan lebih baik akibatnya. (QS. An-Nisa ayat 59).

Kemudian dalam hadits dijelaskan "Ulama adalah pewaris Nabi" (HR. At-Tirmidzi). Jadi secara epistimelogis pendidikan Islam memiliki konsep yang jelas, walaupun Alqur'an dan Hadis itu bukanlah sebuah konsep, tapi dengan membaca dan memperhatikannya cara pandang dan cara berpikir akan tumbuh dan dapat melahirkan langkahlangkah konkrit dalam mendidik manusia. Dan akan jauh semakin sempurna dengan adanya formulasi kaidah istimbat hukum yang digagas oleh para ulama-ulama mujtahid dan juga ulil amri (pemerintah). Dengan kata lain asas-asas pendidikan Islam cukup jelas dan terang yang dipadu dengan usaha aqal dalam menangkap makna-makna dibalik pemaparan Alqur'an dan Hadits.

Pelaksanaan pendidikan Islam berawal dari suatu pemahaman terhadap tiga term (kata kunci), yaitu al-Tarbiyah (pengasuhan yang baik), At-Ta'lim (pengajaran) dan At-Ta'dib (akhlak, penanaman pengetahuan yang dilandasi dengan adab). Ketiga istilah ini dalam tataran normatif, historis dan filosofisnya sama-sama memiliki argumentasi yang kuat. Walaupun sebetulnya ada perdebatan panjang dikalangan ahli dari ketiga istilah tersebut, dalam diskusi kali ini tidak menjadi fokus utama (Lihat AlAttas, 1990: 34-53 dan 64-83). Untuk harmonisasi dari ketiga istilah tersebut disini diketengahkan bahwa istilah pendidikan Islam telah diformulasikan melalui kesepakatan bersama oleh para ulama dan ilmuwan muslim se-dunia pada perhelatan akbar pada tahun 1977 di University of King Abdul Aziz dengan mendefinisikan pendidikan Islam adalah keseluruhan makna atau pengertian yang tersimpul dalam terma al-Tarbiyah (pengasuhan yang baik), At-Ta'lim (pengajaran) dan At-Ta'dib (akhlak). (Al Rasyidin, 2012: 119). Sehingga dalam paparan selanjutnya pemakaian makna dari ketiga istilah tersebut,tidak menutup kemungkinan makna yang digunakan bergantian sesuai kebutuhan pembahasan.

Al Rasyidin berpendapat pemahaman yang komperhensif terhadap al-Tarbiyah, At-Ta'lim dan At-Ta'dib dapat memberi pengertian bahwa pendidikan Islam adalah upaya sungguh-sungguh untuk menciptakan lingkungan pendidikan yang kondusif sehingga peserta didik memungkinkan untuk dapat mengembangkan dirinya. Pengembangan diri yang dimaksud haruslah dapat menyentuh ranah-ranah fisik maupun psikis, material dan immaterial atau jasmani dan rohani. Selain itu daya-daya yang dimiliki oleh sturuktur jasmani manusia harus diperhatikan. Maka hubungan pengembangan fisik dan 
potensi yang dimiliki manusia harus berjalan secara integral. Dengan memperhatikan kemungkinankemungkinan seperti itulah tujuan pendidikan Islam akan terrealisasi dengan baik. (Al Rasyidin, 2012: 119).

Adapun daya-daya yang dimiliki manusia yang akan menjadi sarana pengembangan dirinya seperti al-jism, alaql, al-nafs dan al-qalb. Optimalnya pemberdayaan daya-daya tersebut akan mampu mengantarkan manusia untuk membayar hutangnya kepada Tuhan Pencipta yaitu menjadi hamba yang mampu menemukan dan mengenali tempat asalnya yaitu alam arwah. Ketika awal penciptaan manusia dalam Islam diyakini bahwa setiap manusia dimintai keterangan tentang prihal penciptaan dirinya. Dalam Alqur'an Allah SWT berfirman:

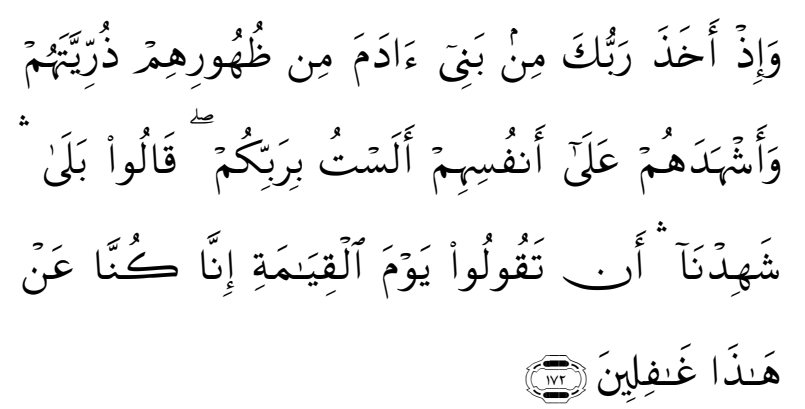

"Dan (ingatlah), ketika Tuhanmu mengeluarkan keturunan anak-anak Adam dari sulbi mereka dan Allah mengambil kesaksian terhadap jiwa mereka (seraya berfirman): "Bukankah aku ini Tuhanmu?" mereka menjawab: "Betul (Engkau Tuban kami), Kami menjadi saksi". (kami lakukan yang demikian itu) agar di hari kiamat kamu tidak mengatakan: "Sesungguhnya Kami (Bani Adam) adalah orang-orang yang lengah terhadap ini (keesaan Tuhan)". (QS. Al-A'raf ayat 172).

$$
\text { Jadi dalam pendidikan Islam }
$$
aktivitas kehidupan hendaknya harus mengacu kepada pencarian serius akan Sang Pencipta. Selain itu pendidikan Islam memiliki tanggung jawab penuh untuk membantu manusia dalam menemukan mutiara tersebut. Ibarat seorang perantau yang sudah lama meninggalkan kampung halamannya, adalah prestasi besar jika ia mampu mengurai kembali mata rantai asal kehidupannya. Sehingga dalam ajaran Islam disebutkan bahwa kampung akhirat itu adalah lebih baik dari pada kampung dunia tempat manusia tinggal sekarang.

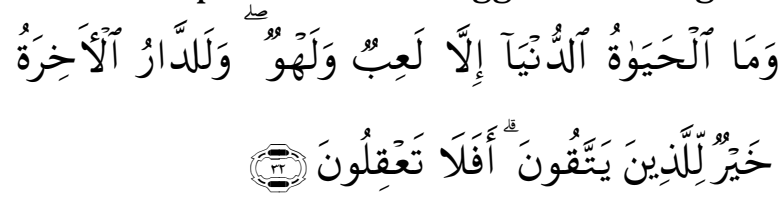

"Dan Tiadalah kehidupan dunia ini, selain dari main-main dan senda gurau belaka. dan sungguh kampung akhirat itu lebih baik bagi orang-orang yang bertaqwa. Maka tidakkah kamu memahaminya?" (QS Al-An'aam ayat 32).

Sebab akhirat adalah pertemuan kembali dengan Allah SWT. Dunia ibarat tempat perantauan yang sifatnya sementara dan akan ditinggalkan menuju kampung sesungguhnya. Rugi besar jika manusia semasa dalam perantauan tidak mampu mengenali kampung asilnya kembali, padahal dulunya ia pernah hidup dan tinggal di sana. Tentu bagi orang seperti itu akan mengalami kegelisahan karena tidak satupun yang ia kenal di sana. Satu-satunya jalan untuk mampu mengenali apa saja yang ada di sana haruslah berdasarkan ilmu dan amal.

Sebuah pencarian membutuhkan kesungguhan. Aktivitas pencarian ilmu pengetahuan dalam Islam merupakan bahagian yang tidak dapat dipisahkan dari upaya pemahaman terhadap tanda-tanda kekuasaan dan ke-Esaan Allah SWT. Hal inilah yang dimaksudkan Allah dalam surah Al-Baqarah ayat 31, yaitu:

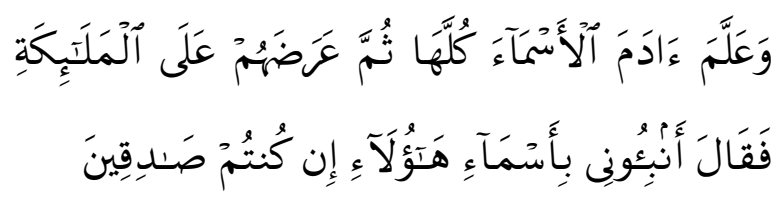

"Dan Dia mengajarkan kepada Adam Nama-nama (benda-benda) seluruhnya, kemudian mengemukakannya kepada Para Malaikat lalu berfirman: "Sebutkanlah kepada-Ku nama benda-benda itu jika kamu mamang benar orang-orang yang benar!". 
Dari ayat ini jelas sekali kata "asmaa" merupakan simbol-simbol pengetahuan yang akan membuat manusia mampu mengenali bentuk-betuk objek yang ada disekelilingnya. Dengan pemahaman semacam ini kehidupan manusia benar-benar tergantung terhadap pendayagunaan perangkatperangkat yang ada dalam dirinya.

Itulah sebabnya para filsuf Muslim banyak memberikan penjelasan tentang siapa sesungguhnya manusia yang diberi ruang kebebasan untuk dapat menginternalisasikan hal-hal yang ada di luar dirinya. Dilatarbelakangi oleh keunikan struktur tubuhnya yang berbeda dengan makhluk yang lain telah memotivasi pemikir muslim melakukan kajian-kajian yang mendalam untuk mengurai tirai dibalik diri manusia itu sendiri sehingga perlakuan terhadap sesama manusia (pendidikan) akan sejalan dengan tujuan penciptaan manusia. Dengan menempatkan manusia pada posisi yang benar, penyelenggaraan pendidikan Islam jauh lebih bermanfaat yang pada akhirnya akan dapat menciptakan tatanan kehidupan yang seimbang, tidak melakukan perbuatanperbuatan yang mencelakai diri dan orang lain. bila prinsip seperti itu telah tertanam dengan baik menjadi sebuah karakter dapatlah disimpulkan keharusan alam dapat berubah, perubahannya akan tetap pada batas-batas wajar dan tidak berlebihan.

Berdasarkan pandangan tersebut pendidikan Islam diyakini mempunyai pengaruh besar dalam kebangkitan segala macam pendidikan, yang sebelumnya dipetik dari prinsip-prinsip yang terdapat dalam agama dan budi pekerti dan diutamakan pula segi kemanusiaan sosial dan kerjasama, seperti persaudaraan, kemerdekaan, persamaan, keadilan dan kesempatan yang sama di samping kesatuan rohaniyah di antara seluruh umat Islam. Ungkapan tentang "Pintu pendidikan terbuka seluas-luasnya bagi siapa saja yang berkeinginan untuk belajar agama dan lain-lain, kapan saja dan di mana saja". Pemahaman semacam ini merupakan prototipe dari pendidikan demokratis yang hakiki di dalam pendidikan dan pengajaran yang diungkap oleh Muhammad 'Athiyah Al-Abrasyi dalam prinsip-prinsip dasar pendidikan Islam atau التربية الاسلامية وفلا سفتها. Dewasa ini, kita telah memiliki perkembangan pada berbagai bidang, ilmiah dan kebendaan. Akan tetapi, sangatlah disayangkan bahwa kita belum sampai bertingkat spiritual dan akhlak yang tinggi seperti umat Islam pada zaman kejayaan dulu. Dari itu sesungguhnya sangat membutuhkan pemikiran dibidang rohani, pembentukan akhlak yang mulia sehingga kita dapat menegakkan kembali keagungan dan kebesaran Islam di masa lalu. (Al-Abrasyi, 2003: 19).

Pendidikan merupakan bagian terpenting dalam kehidupan, karena dari kehidupan itulah yang bisa membedakan antara kehidupan manusia yang dialami oleh hewan. Pendidikan secara umum (formal maupun non formal) pada dasarnya merupakan kebutuhan yang primer dengan manusia, baik secara individu maupun sebagai warga negara, yang menuju kearah terbentuknya kepribadian yang utama. (Marimba, 1981: 95).

\section{MANUSIA PERSPEKTIF PENDIDIKAN ISLAM}

Dalam sumber asasi ajaran Islam disebutkan bahwa manusia disebutkan dengan berbagai peristilahan. Terma yang digunakan Alqur'an tentang siapa manusia menunjukkan manusia itu adalah makhluk yang terdiri dari fisik dan psikis. Adapun istilah-istilah tersebut yaitu al-Insan, alBasyr, dan Bani Adam. (Baharuddin, 2004: 64).

Kata al-Insan memiliki beberapa derivasi atau jenis kata yaitu al-Ins, al-nas, dan al-Unas. Kata al-Ins disebutkan dalam Alqur'an sebanyak 18 kali. Kata alIns memiliki arti jinak dan penggunaannya selalu dipakai dan 
dihubungkan dengan kata al-Jinn yang berarti buas atau samar. Kedua makhluk ini diciptakan Allah SWT agar senantiasa mengabdi kepada-Nya, seperti dalam QS. Al-Zariyat ayat 56 "Tidak Aku ciptakan Jin dan Manusia kecuali hanya untuk beribadah kepada-Ku". Kedua makhluk ini disinyalir secara normatif sama-sama berpotensi untuk masuk surga dan juga tidak menutup kemungkinan untuk berpaling dari ibadah sehingga masuk neraka. Dengan demikian al-Ins sebagai sebutan bagi manusia menggambarkan bahwa manusia memiliki potensi jiwa yang dapat berubah disaat-saat tertentu. (Baharuddin, 2004: 70-74). Kemudian Kata al-Nas disebutkan dalam Alqur'an sebanyak 243 kali yang memiliki tekanan makna sebagai makhluk penghuni alam semesta berasal dari keturunan Adam. Kata ini tidaklah pernah digunakan untuk arti manusia secara fisik. (Al Rasyidin, 2012: 13). Bila dilihat dengan seksama bahwa Allah SWT ternyata menggunakan istilah al-Nas ini dalam berbagai aspek pembicaraan. Misalkan untuk menunjukkan sebuah prinsip yang berlaku untuk umat manusia, artinya penggunaan istilah ini bukan hanya ditujukan untuk umat muslim tapi bersifat universal karena mengandung nilai-nilai yang dipandang baik untuk seluruh umat manusia, misalkan hidup damai dan tidak saling berperang. (Baharuddin, 2004: 8288). Selain itu kata al-Unas bentuk jamak dari al-Insan digunakan Alqur'an sebanyak 5 kali. Secara normatif kata ini dipakai untuk menyebutkan manusia secara berkelompok atau bersuku-suku, kelompok pelaku kriminal, dan kelompok yang berstatus baik dan buruk di akhirat. (Baharuddin, 2004: 74-76).

Peristilahan lain yang digunakan Allah menyebutkan manusia adalah alBasyr. Al-Basyr secara bahasa adalah fisik manusia. Alqur'an menggunakan kata ini sebanyak 36 kali dengan tekanan pembicaraan berbeda-beda. Kata ini selain digunakan untuk menerangkan sisi kemanusiaan Rasul dan Nabi seperti makan, minum dan lain-lain juga digunakan dalam tema seperti proses penciptaan manusia, manusia sebagai manusia pada umumnya, kulit manusia, dan manusia semuanya akan mati. Sehingga dapat dipahami bahwa manusia adalah salah satu makhluk biologis yang memiliki fisik, artinya ada gejala umum yang melekat pada fisik sehingga manusia sangat tergantung kepada kodrat alamiahnya. (Baharuddin, 2004: 65-69).

Sedangkan kata Bani Adam yang digunakan Alqur'an terhitung sebanyak 7 kali yang secara bahasa adalah anak Adam. Konteks pembicaraa dengan istilah Bani Adam ini menggambarkan bahwa manusia punya keharusan memakai pakain untuk memperelok tubuh dan menutup aurat, tentang keimanan, penjelasan tentang musuh yaitu syaitan. Sehingga manusia pada tataran ini adalah makhluk istimewa yang memiliki fitrah keagamaan, peradaban dan kemampuan memanfaatkan alam. Artinya manusia memiliki dua relasi yaitu hablum minaAllah dan hablum min al-nas. (Baharuddin, 2004: 88-91).

Pemaparan singkat dari terma manusia menurut perspektif sumber asasi Islam ini dapat memberi pengetahuan berharga tentang siapa sesungguhnya manusia. Sampai pada tahap ini dapat dimengerti bahwa manusia adalah makhluk yang tidak berdiri sendiri. Dibalik keindahan surah (rupa) atau bentuknya pada hakikatnya muatan yang terkandung di dalamnya jauh lebih indah, itulah yang sering disebut dengan psikis (daya fisik). Daya-daya yang melekat terhadap manusia dalam arti kumulatif adalah sarana penunjang sehingga manusia mampu untuk menentukan sejauh mana manusia dapat berkesistensi di dalam homogenitas kehidupannya.

Harmonisasi kehidupan personal manusia dengan kehidupan di luar dirinya tentu harus didasari oleh sebuah pemahaman pada sinkronisasi antara hakikat manusia dengan terma konseptual pendidikan Islamitu sendiri. Dalam 
pendidikan Islam diyakini bahwa manusia adalah mawujud atau yang diadakan oleh yang Maha Wujud, dia diberikan potensi lahiriyah dan batiniyah. Secara umum memang manusia sama yaitu sama-sama memiliki watak kemanusiaan seperti wujudnya sama, gejala jism atau fisik sama-sama butuh terhadap makan, minum, sandang, pangan dan sebagainya. Namun pada sisi lain,kemampuan menggunakan fungsi daya-daya fisik mengharuskan mereka berbeda dalam mencapai status dihadapan oleh Allh SWT. Bagi manusia yang tidak mampu menggunakan fisik dan dayanya terhadap hal-hal yang positif neraka menjadi tempat kembalinya. Artinya perilaku negatif seperti kriminal, memakai narkoba, menipu, berbohong, dan menguras alam untuk kepentingan hasrat nafsu (kapitalis), ini merupakan indikator aktivitas yang beralamatkan neraka. Namun jika sebaliknya aktivitas yang didasari oleh kesadaran terhadap hutang kehidupan terhadap Pencipta tempat mereka adalah surga. Itulah sebabnya manusia disebut dengan makhluk horizontal dan vertikal. Punya tanggung jawab terhadap sesama dan dan kewajiban kepada Allah yaitu beribadah, baik ibadah mahdoh mupun ghairu mahdoh.

Hanya saja untuk mencapai predikat berhasil di sisi Allah SWT sebagai pencipta peran pendidikan Islam sangat dibutuhkan. Konfirmasi Alqur'an tentang manusia yang memiliki kemungkinan dan kencenderungan tetap pada kodrat penciptaanya (bertauhid) dan melupakan kesaksian primordial terhadap penciptanya (tidak bertauhid) menjadi modal berharga bagi pendidikan Islam. Sehingga pemetaan formulasi konsep pendidikan ideal lebih memungkinkan terwujud. Potensi yang ada dalam diri manusia sangat berharga, itu merupakan kekuatan adaptif dalam berintekrasi dengan realitas. Kekuatan adaptif ini menjadi penyokong untuk menggali realitas yang ada disekelilingnya.
Kepekaan manusia terhadap realitas merupakan langkah konkrit untuk memastikan dirinya menjadi orang yang terbuka terhadap pengalaman dan pengetahuan baru dan hal-hal baru yang melekat padanya. Hanya saja keterbukaan terhadap realitas ini harus tetap dalam bimbingan Sang pemilik realitas itu sendiri yaitu Allah SWT. (Muhmidayeli, 2013: 48). Inilah yang disebut dengan kenyataan manusia sebagai makhluk hablum minaAllah dan hablum min al-nas. Jadi tak hayal jika kekuatan-kekuatan itu diarahkan dengan tepat, intensitas keberhasilannya jauh lebih berkualitas bila dibandingkan dengan pengajaran yang kering nilai maupun pembiaran secara alami dengan harapan tumbuh dan berkembang apada adanya.

Jadi pendidikan Islam berkehendak agar tranformasi ilmu pengetahuan sejalan dengan pemeliharaan, pemupukan dan pemastian akan tumbuh kembangnya fisik dan psikis manusia secara sehat dan positif, persoalan ini juga harus berangkat dari niat yang tulus sebagai cerminan dari $a d a b$ atau akhlakul karimah sebagaimana konsep pendidikan Islam yang telah digagas oleh para ulama atau pemikir muslim. Pendidik dan peserta didik dalam pendidikan Islam harus benar-benar berupaya mengosongkan diri dari gejalagejala penyakit hati yang dapat meleburkan niat tulus ikhlas karena Allah.

\section{ILMU PERSPEKTIF PENDIDIKAN ISLAM}

Islam tidak mengenal konsep dikotomi sebagaimana yang terjadi pada konsep pengembangan ilmu pengetahuan oleh kelompok tertentu. Dalam Islam, Tauhid adalah sumber Intrinsik Integrasi. Pemisahan dan disintegrasi antara ilmu agama dan non agama atau antara agama dengan sains adalah sumber malapetaka. Seperti disebutkan Al-Attas (1981: 195) besarnya jumlah malapetaka dewasa ini disebabkan oleh ilmu pengetahuan yang tidak di dasari oleh nilai-nilai intrinsik. Adalah tantangan terbesar yang secara diam-diam telah timbul dalam ditengah- 
tengah kehidupan pengetahuan yang kering nilai. Pengetahuan yang dipahamkan sekarang dan disebarkan merupakan pengetahuan yang sifatnya kehilangan maksud yang sebenarnya sebagai akibat dari pemahaman yang tidak adil. Keragu-raguan yang digagas oleh peradaban Barat sebagai epistimologis pencarian kebenaran turut memberi warna terhadap kekacauan umat manusia.

Sementara Islam memandang sumber ilmu adalah satu yaitu Tuhan dan harus beranjak dari sebuah keyakinan mutlak terhadap Tuhan itu sendiri. Tauhid menjadi landasan atau fondasi bagi keterkaitan segala sesuatu. Tauhid telah menegaskan bahwa segala sesuatu berasal dari prinsip Pertama, segala sesuatu secara terus menerus ditopang dan dipelihara oleh prinsip Pertama tersebut. Tidak ada alasan untuk memisahkan wujud dengan Wujud Azali karena biar bagaimanapun semuanya saling terkait dan terhubung. Hal semacam ini telah banyak dinyatakan oleh para filsuf muslim seperti al-Farabi secara implisit membuktikan bahwa ilmu agama dan sains, agama dan filsafat, adalah satu kesatuan yang utuh. (Humaidi, 2015: 226227). Oleh karena itu sangat tepat apa yang dikatakan oleh Rumi ketika mengomentari hadits tentang hubungan ulama dan umarah "sebagus dan secemerlang apapun buah pikiranmu, tidaklah lebih hebat dari buah pikiran Nabi. Jadi janganlah terlalu mengandalkan akal dan pikiran. Jadilah orang yang selalu mengemis dan takut dihadapan Allah SWT". (Rumi, 2016: 33). Sementara Osman Bakar (1995: 11) menyebutnya semangat ilmiah dalam Islam tidaklah bertentangan dengan kesadaran religius (agama), karena ia merupakan bagian yang terpadu dengan Keesaan Tuhan. Semangat demikian tentu lahir dari kesadaran tauhid dan mengalir secara historis dari pengetahuan agama sampai kepada ilmu-ilmu alam, sosial dan lainnya yang melibatkan tokoh-tokoh besar dalam sejarah Islam.

Itulah sebabnya dalam peradaban atau tradisi akademis Islam istilah ilmu disebut dengan 'ilm. Kata ini memiliki kaitan dengan dengan salah satu nama Allah swt. Allah memiliki 99 nama yang salah satunya adalah 'ilm tersebut. Dalam Alqur'an sendiri Allah menyebut diri-Nya sebagai 'Alim dan 'Alima. Kata-kata ini sering Allah swt ulang-ulang sehingga tergambarlah bagi kita bahwa Allah swt adalah sumber mutlak ilmu pengetahuan sehingga secara otomatis Islam sangatlah menghargai ilmu. (Al-Rasyidin dan Ja'far, 2015: 55). Maka tidak benar kalau ada yang menyangkakan bahwa Islam tidak menghargai ilmu. Hal ini jauh sebelum saat sekarang Abduh (19987: 18 dan 23) telah membantah itu dan memberikan bukti historis bahwa Islam benar-benar agama yang menjungjung tinggi kebenaran dan ilmu pengetahuan bahkan lebih jelas ia mengatakan Islam memiliki pitu seluas-luas bagi ahli ilmu dan ahli pikir. Kenapa tidak kebenaran dan ilmu bagi Islam merupakan karunia Tuhan sehingga tidak ada halangan bagi Islam untuk menerimanya dari manapun sumbernya. Hal ini seperti diungkapkan oleh Al-Kindi "Kita tidak perlu malu mengakui kebenaran dan mengambilnya dari sumber manapun datangnya, kalaupun kebenaran tersebut dibawa kepada kita oleh generasi-generasi terdahulu dan bangsa-bangsa asing. Sebab bagi orang yang mencari kebenaran, tak ada nilai yang lebih tinggi dari kebenaran itu sendiri, kebenaran tak pernah merendahkan atau menghindar dari orang yang menerimanya, tapi sebaliknya membuatnya jadi mulia. (Stanton, 1994: 102).

Jadi dalam Islam kedudukan ilmu dalam arti luas dan sempit terjalin indah dan rapi dengan mengarah kepada satu kesimpulan bahwa ia akan mengalir secara vertikal berbentuk tasybih yang merupakan wujud dari bentuk rasa 
syukur manusia terhadap pemberi dan sumber ilmu tersebut (Allah swt).

Kenyataan itulah yang membuat AlAttas menyebutkan bahwa proses pendidikan Islam atau proses tumbuh dan berkembangnya manusia harus dilandasi oleh rasa kasih sayang baik secara horizontal maupun vertikal. Sedangkan proses penanaman ilmu tidak boleh dangkal apalagi kering nilai. Sehingga menurutnya upaya seorang pendidik dalam mendidik baik dari arti fisik maupun psikis harus benar-benar beranjak dari kesadaran yang tersimpul dalam arti Adab atau Akhlak. Jika adab tidak menjadi landasan dari pelaksanaan pendidikan maka kekacauan akan terjadi. Sebab boleh jadi orang dapat tumbuh dan berkembang dan mampu mempelajari berbagai disiplin ilmu, namun karena adanya distorsi terhadap nilai-nilai yang termuat dalam adab maka pemanfaatan ilmu pengetahuan yang mereka miliki akan sembarangan. Rasa kapitalisme akan tumbuh subur karena ukuran aktivitas harus dapat menghasilkan dalam arti kuantitatif. Sebagai hipotesis bisa jadi kekacauan yang terjadi sekarang ini, mulai dari kehidupan politik, ekonomi, sosial, pengurasan alam yang berlebihan diakibatkan oleh hilangnya adab dari perolehan ilmu pengetahuan.

Namun sebelumnya, kiranya perlu diketengahkan bagaimana sesungguhnya memahami dan memperoleh ilmu pengetahuan. Sebab kekeliruan atau ketidak pahaman piranti apa saja yang menjadi sarana penyerap ilmu pengetahuan, kekacauan aksiologis dari capaian kumulatif ilmu pengetahuan akan tidak terkontrol. Padahal adalah suatu kenyataan lepas kontrolnya ilmu pengetahuan oleh religiusitas akan berakibat fatal terhadap kehidupan umat manusia masa kini dan masa yang akan mendatang.

Al-Ghazali menyebutkan bahwa secara psikologis dalam diri manusia ada 3 perangkat yang dapat memperoleh ilmu pengetahuan. Mekanisme kerja perangkat ini satu sama lain berbeda. Adapun ketiga perangkat yang dimaksud adalah 'aql (akal), qalb (hati), ruh (nyawa) dan nafs (jiwa).'Aql memiliki dua pengertian, yaitu:

1. 'Aql adalah pengetahuan yang dapat dikategorikan kepada 3 hal yaitu a) alulum al-dharuriyyah (aksiomatis) yaitu suatu yang muncul dalam diri manusia pada saat mencapai usia tertentu. Mencakup kemungkinan sesuatu yang mungkin (jawaz al-ja'izat) dan kemustahilan yang mustahil (istihalat al-mustahilat). b) pengetahuan yang diperoleh dari pengalaman dan interaksi dengan lingkungan. Pengetahuan semacam ini bertambah sejalan dengan bertambahnya pengalaman manusia. Pengalaman ini dapat berkembang sehingga tersistematisasi menjadi pengetahuan yang lebih kompleks. c) pengetahuan yang memungkinkan manusia mengembangkan kemampuan mengendalikan diri dan hawa nafsunya, sehingga tidak terjebak kepada kesenangan sesaat yang biasanya berakibat buruk.

2. 'Aql pengertian kedua ini adalah washf (kualitas) yang mampu membedakan manusia dan hewan, sehingga memungkinkan manusia memahami al-ulum al-nazariyyah (spekulatif). Akal semacam ini adalah perangkat penyerap pengetahuan.

Qalb juga memiliki dua pengertian, yaitu sebagai entitas fisik yaitu hati atau segumpal daging dan sebuah esensi paling mendasar dalam diri manusia yang dapat menalar dan mengetahui informasi dan pengetahuan (haqiqat al-insan al-mudrik al-alim). Kemudian ruh (jiwa), memiliki makna yang sama dengan qalb dan secara material berbeda. Terakhir adalah nafs dengan dua makna yaitu entitas immaterial yang merupakan sumbersumber negatif manusia seperti marah, dengki, dan nafs sebagai esensi manusia yang berfungsi sebagai tempat penyimpanan pemahaman dan pengetahuan. (Asari, 2012: 62-54). 
Jadi dalam tradisi Islam ulama benar-benar memiliki kesadaran Ilahiyah untuk mengungkap rahasia dibalik diri manusia sebagai makhluk yang bagus rupa. QS. At-Tin ayat 4 menyebutkan.

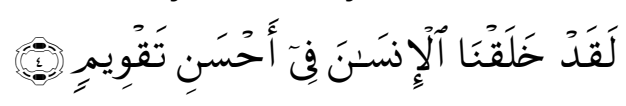

Artinya: Sesungguhnya kami Telah menciptakan manusia dalam bentuk yang sebaik-baiknya .

Selain ketiga sarana di atas, perolehan ilmu pengetahuan menurut Imam Al-Ghazali ada satu lagi, ini biasanya diposisikan puncak dari usaha pencarian kebenaran. Manhaj terakhir ini bersifat spritual tanpa ada hubungan dengan dunia materi dan tidak melibatkan proses empiris atau rasional sama sekali. Sistem kerja metode ini benar-benar melampaui batas-batas inderawi dan berwarna sufistik. (Asari, 2012: 80). Namun sayang dalam diskursur modern epistimologi semacam ini sering menjadi perdebatan panjang dan bahkan tidak mendapat tempat bagi kalangan tertentu karena mereka menganggap proses semacam itu tidak dapat dipertanggung jawabkan secara ilmiah.

Dengan demikian semakin tampak jelas bahwa khazanah pendidkan Islam kaya dengan berbagai formulasi tentang bagaimana proses meraih ilmu. Proses pencarian dan pemerolehan ilmu pengetahuan sarananya tidak lain adalah ada dalam diri manusia. Pemeliharaan terhadap perangkat-perangkat yang ada dalam diri manusia menjadi sebuah keharusan dan dalam Islam hal ini disebut dengan instilah hifdz al-nafs (memelihara diri). Dalam sebuah pepatah dijelaskan "di dalam badan yang sehat terdapat jiwa yang kuat". Bahkan dalam sebuah hadits, Nabi Saw pernah berucap:

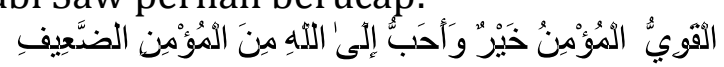

Artinya: Orang mukmin yang kuat lebih baik dan lebih dicintai oleh Allah stw. dari pada orang mukmin yang lebih.

Berarti memastikan badan yang sehat adalah sebuah kewajiban bagi Islam, karena dengan kondisi seperti itulah optimalisasi mencari ilmu sebagai bentuk penghambaan kepada Allah dapat menumbuhkan rasa cinta yang semakin mantap kepada-Nya yang merupakan manisfestasi insan kamil.

Untuk mencapai derajat insan kamil yang sesungguhnya dalam pendidikan Islam sebetulnya tidak cukup hanya penguasaan terhadap ritual ibadah saja. Tapi banyak disiplin ilmu harus dikuasai. Seperti pernah diungkapkan Mulyadhi Kartanegara dalam postingannya di facebook bahwa meraih insan kamil itu mau tidak mau harus membukakan diri terhadap luasnya cabang ilmu dalam Islam. Pernyataan beliau ini kelihatannya sebagai respon terhadap kondisi umat sekarang yang sering terjebak terhadap simbol-simbol keagamaan, walaupun mempertahankan simbol-simbol keagamaan sebuah keharusan lantas tidak berarti tertutup terhadap sesatu yang bisa jadi jauh lebih relevan terutama terhadap keberlangsungan hidup umat manusia di abad 21 ini dan di abad-abad mendatang. Seperti diketahui kehidupan sosial, ekonomi, politik, budaya, agama dan pengurasan alam yang berlebihan yang mengakibatkan perubahan iklim semakin buruk benar-benar membutuhkan ulama dalam arti yang sesungguhnya yaitu ahli dalam bidang multi disipliner.

Adapun klasifikasi ilmu dalam tradisi akademis Islam sangat beragam, namun dalam artikel ini hanya dimuat beberapa klasifikasi saja. Seperti dirumuskan oleh Al-Farabi bahwa cabangcabang ilmu adalah ilmu logika dan bahasa masuk dalam wilayah ilmu alat; ilmu metafisika, matematika dan fisika sebagai rumpun ilmu teoritis; ilmu etika dan politik sebagai ilmu praktis; ilmu-ilmu agama seperti kalam, fikih. Ilmu kalam dimaksudkan untuk menjelaskan nilainilai transenden, sedangkan ilmu fikih menjelaskan nilai-nilai praktis kaitannya dengan kehidupan manusia sehari-hari.

Tidak dipungkiri bahwa hari ini kehidupan umat manusia sangat jauh lebih muda dibanding masa-masa 
sebelumnya. Perkembangan ilmu pengetahuan, teknologi, informasi dan komunikasi telah menjadikan dunia semakin sempit. Batas-batas kehidupan telah dirobohkan. Perpindahan manusia dalam satu waktu ketempat lain kapasitasnya cukup besar dengan memakai alat transportasi baik ia pesawat, kapal, mobil, motor dan sebagainya. Pertukaran informasi beredar sangat cepat melalui media elektronik dengan berbagai macam jenisnya. Percakapan umat manusia lintas negara, bangsa, suku, ras dan agama tidak lagi dianggap tabu. Prestasi umat manusia demikian tentu memiliki nilai positif. Namun dalam waktu yang bersamaan capaian-capaian tersebut telah menciptakan problem baru manusia itu sendiri.Namun perlu disadari cabangcabang ilmu yang uraikan Al-Farabi tidak serta merta membuatnya jadi leberalis tetapi ia tetap memiliki konsistensi bahwa agama dan sains memiliki satu kesatuan utuh atau terintegrasi. (Humaidi, 2015: 227-228). Bila dilihat para ilmuwan non muslim sangat beda jauh cara pandangnya terhadap agama dan sains. Seperti fakta terbaru oleh Stephen Hawking berpandangan Tuhan bukanlah pencipta alam semesta karena alam tercipta secara spontan tanpa disebabkan diciptakan oleh siapa pun. Hawking berkeyakinan bahwa Tuhan sudah bertransformasi dan menjelma di alam semesta dengan mengambil bentuk hukum gravitasi. (Humaidi, 2015: 229).

Pandangan Hawking ini dalam perspektif yang lebih visioner sangat berbahaya, sebab hilangnya peran Tuhan dalam pengaturan alam semesta akan menghalalkan segala bentuk cara asal visi dan misi riset dan eksprimen tercapai, tidak pandang bulu apakah berdampak negatif terhadap manusia dan makhluk hidup lainnya. Jika di Indonesia prinsip ini terjadi, sebagai negara agraris yang berlimpah sumber daya alam sudah barang tentu mobilisasi eksploitasi terjadi yang semata-mata untuk memenuhi kebutuhan pemodal.

\section{MANUSIA PARIPURNA ORIENTASI TERAKHIR PENDIDIKAN ISLAM}

Konsep mengenai manusia paripurna (insal kamil) dalam Islam merupakan kajian yang cukup menarik. Insan kamil adalah sebuah keserasian dua bentuk dalam diri manusia. Bentuk yang pertama adalah ada kesempurnaan dari segi wujud yang meliputi semua perangkat-perangkat yang ada dalam diri manusia. Kesempurnaan semacam ini adalah anugerah dari Allah Swt. dan juga merupakan hasil dari manifestasi atas kemampuan menjaga diri dari segala bentuk yang dapat melukai dan membahayakan diri serta kesanggupan untuk memanfaatkannya. Sedangkan yang kedua adalah kesempurnaan pengetahuan. Kesempurnaan pengetahuan ini didadasari oleh keingintahuan untuk memperoleh pengetahuan. Rasa ingin tahu itupun mengharuskan manusia untuk mampu memanfaatkan atau menggunakan potensi yang ada dalam dirinya untuk meraih ilmu pengetahuan sebanyak-banyaknya. Namun tidak hanya cukup sekedar memperoleh, tapi hendaknya ilmu yang dimiliki manusia digunakan sejalan dengan tuntunan syariat yang dibawa oleh utusan-Nya.

Ketika menjaga diri sejalan dengan pemanfaat potensi badani yang terdapat dalam diri manusia inilah yang akan mampu menghantarkan manusia kepada kesempurnaan. Terkadang ada orang berpikir apa mungkin manusia dapat mencapai sempurna? Perlu ditekankan sempurnanya manusia tidaklah sama dengan kesempurnaan Tuhan. Kesempurnaan manusia hanya sekedar kesempurnaan menurut kadar manusia itu sendiri. Kesempurnaan yang manusia peroleh adalah hadiah Allah Swt atas upaya manusia dalam menginternalisasikan dan merealisasikan cita-cita dasar penciptaannya. 
Oleh karena demikian, perlu disadari bahwa kesempurnaan manusia akan terwujud ketika apa yang diharapkan oleh Allah Swt. ketika menciptakannya terwujud dengan baik. Maka ketika manusia mampu memanfaatkan perangkat yang ada dalam dirinya dan menggunakannya untuk mencari ilmu tentang hakikat kebenaran maka pada saat itulah derajat manusia paripurna berhak mereka sandang. Jadi sinkronisasi antara aktivitas manusia dengan motif dasar penciptaannya inilah yang disebut sebagai orientasi terakhir pendidikan Islam. Muara dari segala praktik aktivitas pendidikan, di dalam Islam tidak boleh keluar dari prinsip dasar tersebut.

Selain itu, ada tiga hal yang menjadi prasyarat tercapainya prinsip dasar pendidikan Islam. Bilamana ketiga hal ini mampu dijadikan tonggak dasar maka dengan optimis dapat dikatakan bahwa cita-cita mewujudkan kehidupan manusia yang paripurna bukanlah hayalan belaka sebab konsep teoritisnya dalam Islam sangat jelas, hanya saja perlu kerja keras untuk mengimplementasikannya. Adapun Ketiga hal tersebut yaitu menyadari tujuan, fungsi dan tugas penciptaan manusia oleh Allah Swt, hal ini juga menjadi orientasi terakhir pendidikan Islam. Jadi kemampuan memahami dan mengimplementasikan ketiga hal ini merupakan barometer berhasil atau tidaknya proses pendidikan yang dilakukan.

Pemahaman kepada tujuan penciptaan manusia adalah modal awal ketika ingin melakukan berbagai kegiatan. Ibarat lembaga, visi misi menjadi landasan utama dalam mengoperasionalakan lembaga tersebut. Sekompleks apapun bentuk kegiatan yang dilakukan oleh lembaga tersebut tetaplah ia mengacu kepada misi visi didirikannya lembaga itu. Dalam Alqur'an Allah Swt. sesungguhnya sudah lama mengisyaratkan bahwa manusia diciptakan tidak main-main, tetapi mereka diciptakan memiliki misi yang sangat jelas. Alqur'an surah al-A'raf ayat 172 :

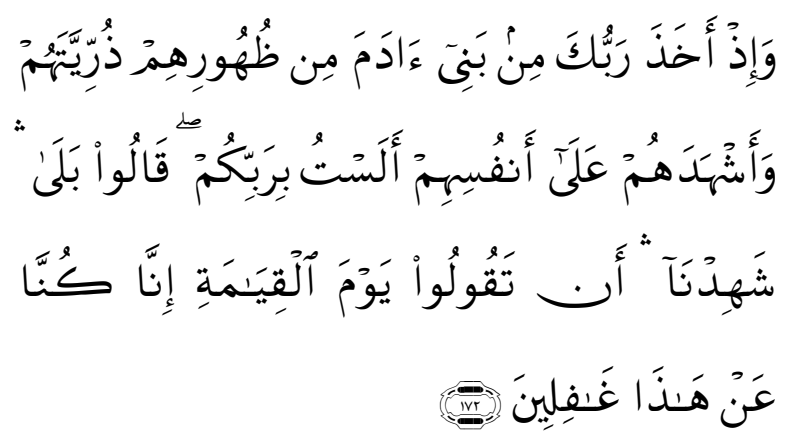

Artinya: Dan (ingatlah), ketika Tuhanmu mengeluarkan keturunan anak-anak Adam dari sulbi mereka dan Allah mengambil kesaksian terhadap jiwa mereka (seraya berfirman): "Bukankah aku ini Tuhanmu?" mereka menjawab: "Betul (Engkau Tuban kami), Kami menjadi saksi". (kami lakukan yang demikian itu) agar di hari kiamat kamu tidak mengatakan: "Sesungguhnya Kami (Bani Adam) adalah orang-orang yang lengah terhadap ini (keesaan Tuhan)".

Dari ayat tersebut jelas sekali Allah swt benar-benar menunjukkan dan menerangkan kekuasaan-Nya. Dia telah mengeluarkan semua manusia sejak Nabi adam hingga manusia yang akan lahir di saat hari kiamat, untuk mempersaksikan kepada mereka bahwa Allah itu Tuhan yang mencipta dan pemilik mereka semua dan bahwa tiada Tuhan selain Dia, sebagaimana Tuhan mencipta mereka dengan dasar tabiat fitrah. (Salim Bahreisy dan Said Bahreisy, 1986: 501). Tabiat fitrah inilah yang menjadi modal berharga dan akan mempengaruhi manusia untuk melangkah mewujudkan cita-cita besarnya (Mujib, 1999: 1).

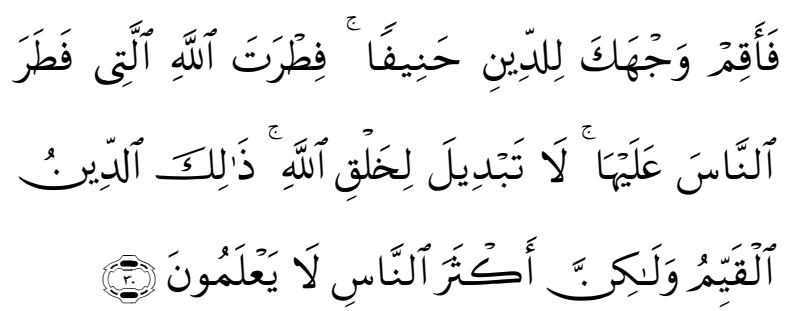

Artinya: Maka hadapkanlah wajahmu dengan Lurus kepada agama Allah; (tetaplah atas) fitrah Allah yang telah menciptakan manusia menurut fitrah itu. 
tidak ada peubahan pada fitrah Allah. (Itulah) agama yang lurus; tetapi kebanyakan manusia tidak mengetahui. (QS. Rum: 30).

Ayat di atas merupakan pertanda bahwa kebutuhan manusia terhadap kehadiran Tuhan memang tidak dapat dinafikan oleh siapapun. Seperti dikemukakan oleh Shihab (1996: 366) manusia sekali-kali tidak dapat melepaskan diri dari Tuhan, karea Ia merupakan kebutuhan asasi. Hanya saja kebutuhan akan kehadiran Tuhan dalam diri manusia berbeda dengan kebutuhan yang lain. Kebutuhan air misalnya akan lebih lama dapat ditangguhkan dibandingkan kebutuhan terhadap udara. Begitu juga kebutuhan makan akan lebih lama dapat ditangguhkan dibandingkan kebutuhan terhadap seksual. Jadi mengenai kebutuhan akan hadirnya Tuhan pada diri manusia justru akan jauh lebih lama lagi mampu ditangguhkan bila dibandingkan kebutuhan-kebutuhan yang disebutkan sebelumnya. Tetapi pada suatu waktu kebutuhan itu tetap akan lahir paling tidak ketika manusia ingin menghadapi kematian. Tuhan akan tetap menjadi tempat bergantung selama manusia masih merasakan wawas, takut dan mengharap.

Begitulah prinsip dasar manusia paripurna yang selalu menjadikan Tuhan sebagai orientasi terakhir dalam aktivitas kehidupannya. Sehingga dalam pendidikan Islam pun gagasan semacam ini menjadi harga mati. Segala proses yang terdapat dalam system pendidikan Islam tetap mengacu kepada prinsip dasar tersebut. Sehingga bagaimana pun kompleksnya khazanah ilmu pengetahuan pada abad 21 ini pendidikan Islam tetap memandangnya sebagai anugerah Tuhan. Pendidikan Islam akan selalu memposisikan dirinya sebagai lembaga yang akan mengintegrasikan berbagai disiplin ilmu untuk tidak terjadi pemisahan-pemisahan yang justru akan membahayakan diri manusia dan alam semesta pada umumnya.
Itulah sebabnya di Indonesia misalnya melalui kementerian agama lembaga-lembaga pendidikan Islam mulai dari Tsanawiyah, Aliyah sampai Perguruan Tingginya tidak alergi dengan ilmu-ilmu umum. Bahkan disiplin-disiplin ilmu umum itu menjadi core kurikulum yang sama pentingnya untuk dipelajari. Islam memandang pemisahan ilmu dengan nilai atau etika sangat berbahaya. Itulah sebabnya Nasr dalam artikel Azra (2010: 9) menyebutkan dengan sangat yakin bahwa ilmu pengetahuan dalam Islam tertata rapi berdasarkan pada ide kesatuan transenden yang merupakan jantung kewahyuan dalam Islam. Islam memandang pengetahuan, baik agama maupun umum pada prinsipnya mengantarkan kepada penegasan kesatuan Tuhan. Berarti dengan prinsip seperti itulah manusia akan benar-benar hadir sebagai insane kamil dengan bekal iman dan ilmu pengetahuan serta beribadah kepada Allah Swt.

Mengenai tentang ibadah dalam pendidikan Islam merupakan buah dari iman dan pencarian akan kebenaran (ilmu pengetahuan). Artinya konsekuensi dari pengakuan akan keesaan Allah bagi insane kamil adalah mengharuskan untuk tunduk dan patuh kepada-Nya atau sering disebut sebagai 'abdullah yaitu hamba Allah Swt. Mengenai persoalan ini Allah Swt. menguraikan dalam Alqur'an:

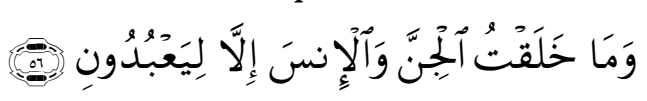

Artinya: Dan aku tidak menciptakan jin dan manusia melainkan supaya mereka mengabdi kepada-Ku.

Jadi, bila merujuk dari sudut pandang pendidikan Islam, penyembahan kepada Allah Swt merupakan target yang terselubung rapi dengan kesadaran penuh untuk mentransformasikan berbagai disiplin ilmu yang dirumuskan menjadi kurikulum. Apapun disiplin yang dipelajari dan diajarkan adalah ibadah yang menjadi subtansi utama. Berpendidikan bukanlah jaminan menjadi insane kamil jika tidak memberikan efek 
kepada peningkatkan ketaatan kepada Allah Swt. peningkatan kuantitas dan kualitas ilmu pengetahuan dan keahlian harus sejalan dengan peningkatan kuantitas dan kualitas ibadah kepada Allah Swt. Dengan cara seperti inilah iman yang disebut-disebut itu akan menjadi bermakna dan tentu akan melahirkan sikap kerendahan diri sehingga harmonisasi kehidupan akan lebih mesra dan santun. Dengan bekal semacam ini tugas-tugas manusia akan lebih berdaya guna dan tepat sasaran. Seperti yang disebut dalam Al-Qur'an manusia adalah khalifah fi al-ardh. QS. Al-Baqarah: 30

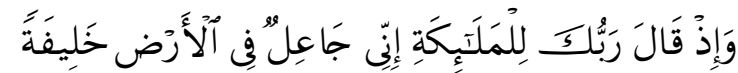

Artinya: "Ingatlah ketika Tuhanmu berfirman kepada Para Malaikat: "Sesungguhnya aku hendak menjadikan seorang khalifah di muka bumi....".

Implikasi ayat ini pada pendidikan Islam dalam mewujudkan insane kamil cukup positif dan konstruktif. (Samsul Arifin, 1994: 53). Manusia dipercayakan oleh Allah Swt. mengemban tugas penguasaan, pemanfaatan, pemeliharaan dan pelestarian alam untuk mencapai kemakmuran. Manusia diamanahi mengemban tugas semacam ini menurut Asy'ari (1992: 38) karena memang manusia dipandang punya kemampuan konseptual dengan watak keharusan bereksprimen secara berkelanjutan sampai tercapainya tujuan. Tentu prinsip itu tidak akan dimiliki oleh makhluk lain. Jadi pada tataran ini manusia dituntut untuk kreatif namun tetap pada batasbatas yang diperbolehkan agama. Kebebasan yang dikaruniakan oleh Tuhan harus dijaga, karena kebebasan dalam pendidikan Islam memiliki makna yang cukup mendasar yaitu merujuk kepada keperibadian diri manusia itu sendiri. Bebas merupakan aktivitas yang dilakukan secara sadar yang disertai dengan rasa tunduk dan patuh kepada ruhani dengan cara mematuhi hukum akhlaqiah yang telah ditetapkan oleh agama. (Musaddad Harahap, 2016: 89).
Insane kamil sebagai output pendidikan Islam bukan hanya pintar dari segi rasio tetapi juga memiliki kepekaan hati yang selalu terikat dengan nilai-nilai tauhidiyah. Bagi pendidikan Islam memang akal tidak selamanya mampu menyelesaikan persoalan kehidupan. Seperti dijelaskan oleh Shihab (1996: 268) adakalanya akal itu buntu tak sanggup menemukan solusi ketika ada persoalan. Misalnya karya seni, ketika akal disuruh untuk menilainya justru dia tidak akan mampu menyelesaikan tugas tersebut, karena akal lebih cenderung beraktivitas dengan konsep hukum kausalitas atau sebab akibat. Sementara untuk menilai karya seni yang lebih berperan di sana adalah hati. Jadi dalam pendidikan Islam hati juga sesungguhnya menjadi sarana untuk memperoleh pengetahuan. Fungsi hati sama pentingnya dengan akal dalam hal pencarian kebenaran yang disebut dengan ilmu pengetahuan terebut.

Maka dengan demikian manusia paripurna berarti manusia yang memahami tentang Tuhan, diri, dan lingkungannya. Jadi pendidikan Islam memiliki prinsip dan keyakinan manusia harus ditempatkan pada posisi makhluk yang diciptakan sehingga ia membutuhkan pendidikan untuk mewujudkan keseluruhan esensi dirinya secara kodrati. Manusia adalah makhluk individu, makhluk social, makhluk bermoral, dan sekaligus makhluk yang ber-Tuhan. Karena ia makhluk ber-Tuhan, maka manusia harus patuh, tunduk dan berterima kasih kepada-Nya dengan melakukan ibadah sebanyak-banyaknya agar segala aktivitasnya tetap pada prinsip dasar kemaslahatan diri, umat dan alam. 


\section{PENUTUP}

Pendidikan Islam sudah hampir empat belas setengah abad menjalankan tugas untuk membimbing manusia menuju kehidupan yang lebih baik, baik dari dimensi lahiriyahnya maupun batiniyahnya. Kehadiran pendidikan Islam ditengah-tengah kehidupan umat manusia merupakan efek dari pemahaman dan penghayatan terhadap ajaran Islam itu sendiri. Sehingga pendidikan Islam tidaklah harus dipahami sebagai pendidikan yang hanya mengajarkan ritual saja melainkan ia juga benar-benar memperhatikan hal-hal yang menjadi kebutuhan umat manusia. Pandangan semacam ini secara argumentative disebabkan oleh pendidikan Islam itu mengakui akan fungsi-fungsi subtansial manusia seperti yang terdapat dalam istilah-istilah manusia yang digunakan oleh Al-Qur'an Hadits Nabi Saw (al-Insan, al-Basyr, dan Bani Adam).

Melalui konsep ilmu pengetahuan dalam pendidikan Islam juga turut memperkokoh argumentasi bahwa pendidikan Islam adalah wahana yang mengakomodasi segala bentuk aktivitas dan penemuan-penemuan manusia. Pendidikan Islam memandang ilmu pengetahuan benar-benar bersumber dari Allah Swt, sehingga para ulama, ilmuwan dan pemikir muslim menempatkan ilmu sebagai hasil pencarian terhadap kebenaran Allah Swt. Dengan konsep inilah pada akhirnya pendidikan Islam tetap mampu eksis dan semakin progresif untuk membantu manusia dalam mewujudkan cita-cita luhurnya.

Selain itu, ilmu pengetahuan juga merupakan satu kesatuan yang utuh yang tidak dapat dipisahkan. Apapun bentuk prestasi manusia dalam pendidikan Islam haruslah tetap membesarkan nama Allah Swt. Sebab, potensi untuk dapat melakukan berbagai kegiatan ilmiah adalah anugerah Allah Swt. Tujuan utama Allah Swt memberikan daya-daya kepada komponen fisik manusia semata-semata untuk dapat memikirkan, memperhatikan kebesaran Allah Swt itu sendiri. Apabila manusia mampu menempatkan Allah Swt sebagai sandaran dari setiap keberhasilannya, penemuanpenemuannya dan sebagainya beberarti derajat insane kamil telah menjadi miliknya. Derajat inilah yang menjadi citacita pendidikan Islam.[] 


\section{DAFTAR RUJUKAN}

Abduh, Muhammad. Ilmu dan Peradaban Menurut Islam dan Kristen, terj. Mahyuddin Syaf dan A. Bakar Usman, Bandung: Diponegoro, 1987.

Al-Abrasyi, M. 'Athiyah. Prinsip-prinsip Dasar Pendidikan Islam, Bandung: Pustaka Setia, 2003.

Al-Attas, Syed Muhammad Al-Naquib. Islam dan Sekularisme, Bandung: Pustaka, 1981.

Al-Attas, Syed Muhammad Al-Naquib. Konsep Pendidikan dalam Islam, Suatu rangka Pikir Pembinaan Filsafat Pendidikan Islam, Bandung: Mizan, 1990.

Al-Rasydin dan Ja'far, Filsafat Ilmu dalam Tradisi Islam, Medan: Perdana Publishing, 2015.

Al-Rasydin, Falsafah Pendidikan Islam, Membangun Kerangka Ontologi, Epistimologi dan Aksiologi Praktek Pendidikan, Bandung: Cita Pustaka Media Perintis, 2012.

Arifin, Samsul. Islam dan Pluralisme Budaya Politik, Yokyakarta: SiPress, 1994.

Asari, Hasan. Nukilan Pemikiran Islam Klasik, Gagasan Pendidikan Abu Hamid Al-Ghazali, Medan: IAIN Press, 2012.

Asy'ari, Musa. Manusia Pembentuk Kebudayaan dalam Al-Qur'an, Yokyakarta: LSIF, 1992.

Azra, Azyumardi. dkk., Strategi Pendidikan Upaya Memahami Wahyu dan Ilmu, Yokyakarta: Pustaka Pelajar, 2010.

Baharuddin, Paradigma Psikologi Islam, Studi Tentang Elemen Psikologi dari Alqur'an, Penelitian Disertasi, Yokyakarta: PustakaPelajar, 2004.

Bahreisy, Salim, dan Said Bahreisy. Terjemah Singkat Tafsir Ibnu Katsir, PT. Bina Ilmu: Surabaya, 1986.

Chodim, Achmad. An-nas, Segarkan Jiwa dengan Surah Manusia, Jakarta: Serambi Ilmu Semeste, 2015.

Humaidi, Paradigma Sains Integratif AlFarabi, Pendasarn Filosofis bagi
Relasi Sains, Filsafat, dan Agama, Jakarta: Sadra International Institute, 2015.

Kasyani, Faidh. Etika Islam Menuju Evolusi Diri, Jakarta: Sadra Press, 2014.

Marimba, Ahmad D. Pengantar Filsafat Pendidikan, Bandung : Al-Ma'arif, 1981.

Muhmidayeli, Filsafat Pendidikan, Cetakan Ke-2, Bandung: Pt Refika Aditama, 2013.

Mujib, Abdul. Fitrah dan Kepribadian Islam; sebuah Pendekatan Psikologis, Jakarta: Darul Falah, 1999.

Musaddad, Harahap. "Refleksi Dinamika Kebebasan Akademis dalam Pendidikan Islam. "AL-THARIQAH 1.1 (2017): 87-103.

Rumi, Jalaluddin. Fihi Ma Fihi, Mengarungi Samudera Kebijaksanaan, Yogyakarta: Grup Relasi Intimedia, 2016.

Shihab, M. Quraish. Wawasan Al-qur'an Tafsir Maudhu'i Atas Pelbagai Persoalan Umat, Bandung: Mizan, 1996.

Stanton, Charles Michael. Pendidikan Tinggi Dalam Islam, Terj. $H$. Afandidan Hasan Asari, Jakarta: Logos Publishing House, 1994.

Tafsir, Ahmad. Filsafat Pendidikan Islami, Integrasi Jasmani, Rohani dan Kalbu Memanusiakan Manusia, Cetakan Ke3, Bandung: PT Remaja Rosdakarya, 2008. 